\title{
The Importance of Developing Communicative Competencies of Future Specialists in the Digital Age
}

\author{
Pesha A.V.1, ${ }^{*}$ Shramko N.V. ${ }^{2}$ \\ ${ }^{1}$ Ural State University of Economics, Yekaterinburg, Russian Federation \\ ${ }^{2}$ Ural State Pedagogical University, Yekaterinburg, Russian Federation \\ ${ }^{*}$ Corresponding author. Email: myrabota2011@gmail.com
}

\begin{abstract}
The paper provides a theoretical and empirical analysis of the demand for communicative competencies in the digital age. The analysis shows that interest in the topic of the formation, assessment and development of communicative competencies in the period from 2010 to the present is constantly growing. The number of publications indexed in the Web of Science and E-library databases has increased by more than 5 times over the reporting period. With the advent of new communication platforms and digital tools, the topic of the development of communicative competencies received a new round of interest from researchers. The results of an empirical study showed a high level of demand for the communicative competencies of young specialists in the modern labour market. The study involved 450 students in the areas of training "management" and "economics" of 6 universities of the Urals and 100 representatives of employers of the Urals. As a result of the study we formulated, the hypothesis that there were no significant statistical differences in the opinions of students and employers regarding the importance of formation, the level of development of modern graduates and students, and also about the possibilities for developing communicative competencies at the university was not confirmed. The results of the study will become the basis for the development of a methodology for the formation, assessment and development of communicative competencies of students, as one of the essential clusters of supra-professional competencies that ensure the competitiveness of graduates of the economy and management in the digital era.
\end{abstract}

Keywords: communicative competence, communicative skills, Industry 4.0., media competency, supra-

professional competencies

\section{INTRODUCTION}

Since the time of the first industrial revolution and the mechanization of production, quite a few technological changes have occurred: from the large-scale spread of the use of electric energy to the spread of digitalization. Cloud technology, the Internet of things, big data, augmented and virtual reality and robotics, which until recently seemed only fiction, are now becoming relevant and somewhat mundane technologies of a new era, Industry 4.0 .

The industrial transformation that is taking place all over the world is oriented towards the future, increasing labour productivity, increasing the efficiency and competitiveness of organizations. The digital economy has a big impact on the labour market, replacing manual labour with smart machines and the introduction of business process automation [e.g. 1,2,3,4].

In order to provide the digital economy with the necessary high-quality workforce, it is necessary, during the implementation of higher education programs, to focus on the development of the skills and competencies that are necessary for the digitalization era [e.g. 5.6].
Of course, digital competencies are becoming one of the most significant for the development of future specialists' competencies of Industry 4.0. However, the basic competencies: cognitive, communicative and self-control competencies are no less relevant for today's students, tomorrow's engines of economic change.

\subsection{Our Contribution}

The purpose of this work is to present the results of an analysis of the views of employers and students in the areas of undergraduate studies in Management, Economics, regarding the importance of communicative competencies in the digital age.

To achieve this goal, we set ourselves a number of tasks: - to conduct a review of the literature on the topic of demand, formation, assessment and development of communicative competencies of specialists;

- present the results of an online survey of employers and university students in undergraduate areas of management and economics, on the importance of developing communication skills in the labour market. 
Research Methods. We have applied a content analysis of the scientific literature and research results of Russian and foreign authors on the importance, formation and development of communicative competencies of young specialists. The methods of classification, comparison, and generalization were used in preparing the literature review. To conduct the empirical part of the study, we conducted an online survey.

Research hypothesis. If we collect the opinions of students and employers regarding the importance of formation, the level of development of modern graduates and students, as well as about the possibilities of developing communicative competencies at the university, the data will not have significant statistical differences.

\subsection{Literature review}

The Interest in the topic of communicative competences began to grow significantly since 1992, until this period in the databases we are analysing there are only a few publications on the topic. Including, one of the first publications of the authors regarding the assessment of students' communication skills appeared back in the late 70s. Nelson L. F. in 1978 studied the communication skills of undergraduate students in the direction of "nursing" [7]. The author conducted a study of selfdevelopment of communication and other skills by graduates and their employers. As a result, differences were found in the estimates of the two groups of respondents. Rosser H. L. in 1979 tested students 'oral communication skills through interviews [8]. Since 1992, publications began to appear in dozens per year, and each year the number of works is increasing. In Figure 1, we demonstrated the dynamics of publications in Russian and English from 2010 to the present, indexed in the Google Scholar database. Since 2010, hundreds of publications a year have appeared on the development, formation and evaluation of communicative competencies and communication skills. In 2019, the number of publications on the subject under study has more than doubled compared to 2010. The number of English-language publications on the topic of communicative competencies posted on the Google Scholar database in 2010 amounted to 6852 publications, and in 2019 their number increased to 14898 (Figure 1).

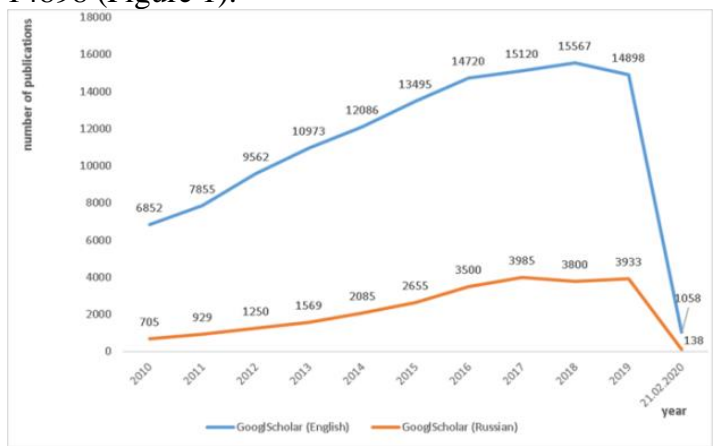

Figure 1 Change in the number of English-language publications and publications in Russian on the subject of communicative competencies and communication skills of Google Scholar for the period 2010-21.02.02.2020

The peak of interest in the topic was observed in 2018, when the number of scientific papers exceeded 15500 . The number of Russian-language publications on the topic increased 5.5 times between 2010 and 2019 (705-2010, 3933-2019) (Figure 2).

The dynamics of publications on the problems of communicative competencies and communication skills in foreign and domestic publications is different. Thus, analysing the number of English-language publications in the Web of Science database, we observe some intensification of interest in the topic, especially noticeable from 2013 to 2016, while the increase in the number of publications in domestic journals and materials of scientific conferences is noticeable, but not constant (Figure 2). In general, there is a positive trend in the interest of scientists, an expansion of the field of research and the presence of active debate about the formation, assessment and development of the communicative competences of the individual in the light of global digitalization.

The growing interest in researching the problems of communicative competencies in the last two decades is largely due to the spread of modern digital technologies, which has also led to large-scale changes in education, the economy, employment and management of organizations. The global labour market is undergoing global shifts and changes, many professions are disappearing, and new, information-oriented technologies are replacing them.

In the era of smart machines, one of the competitive advantages of specialists is the ability to effectively interact with other people, directly or through modern technologies, to be confident and express their position, listen and convince, speak foreign languages and use active listening skills. The study of supra-professional competencies and their importance in the modern world is interdisciplinary. Works on supra-professional competencies and communicative competencies are found in such fields of knowledge as pedagogy [e.g. 9,10,11,12] of sociology and social sciences [e.g. 13,14,15] economics [e.g. 16,17,18], psychology [e.g. 19,20,21] and others.

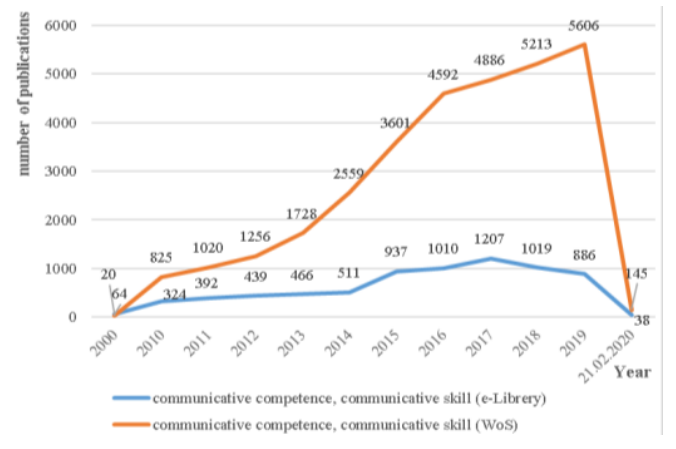

Figure 2 The dynamics of publications on the subject of communicative competencies in the Web of Science and e-Library databases for the period from 2000 to Feb.2020 


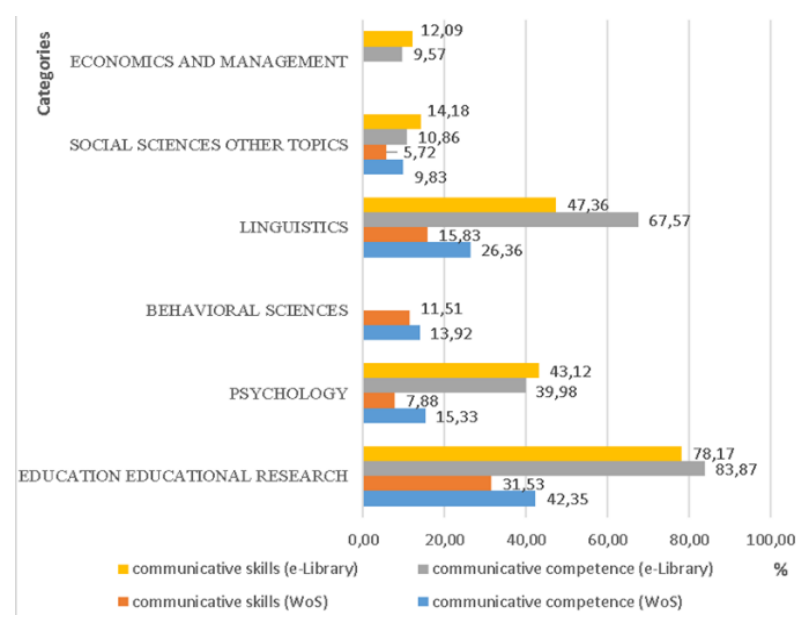

Figure 3 Scientific categories with the largest number of publications on the topic of Communicative competence in the Web of Science and E-library database for the period from 2000 to Feb.2020 (in\% of the total number of publications)

Communication is what makes a person learn, make discoveries, and share his ideas. By the commutative competencies of a modern specialist, we understand the ability of a person to be effective in any communication situation, choose the appropriate model of speech behaviour, persuade and influence, communicate confidently and calmly, show active listening skills and use gestures and pauses, speak foreign languages. In our opinion, the cluster of communicative competencies includes a number of competencies: intersectoral communications; understanding of the meanings; multilingualism and multiculturalism; negotiation and persuasion, and media literacy as a cross-cutting competency between clusters of digital and communication competencies.

In this review, we have analysed the following relevant issues that are related to the definition of the conceptual framework for the development of a theoretical and methodological model for the development, assessment and formation of students' communicative competencies:

- How to assess the degree of development of the communicative competencies of university students?

Interview methods - self-assessments and assessments of communicative competencies are the most common method (e.g. 21, 22, 23). Presentations [24], which are used not only for assessing communicative competencies, but also as a tool for their development. Testing is also one of the methods for studying the level of development communicative competencies of students [e.g. 25]. The study of behaviour during the educational process allows us to evaluate the development of communicative competencies by certain predicates [e.g. 26].

- What pedagogical and practical tools are used to develop students' communicative competencies? Communicative competencies can be developed through the preparation and presentation of presentations [e.g. 24], completing assignments through social networks [e.g. 27], the organization of cultural and leisure activities [e.g.28]. Most of the authors' studies are aimed at exploring the possibilities of developing intercultural and multilingual competence [e.g. 14,29]. Elboubekri A. (2017) [27] conducts a study of the use of modern digital technologies, including social networks for studying foreign languages and substantiates the effectiveness of their use for the development of intercultural communications in interaction with native speakers of a foreign language.

- How does the development of communicative competencies affect the competitiveness of a modern specialist?

A number of studies in the field of economics and management have been devoted to this issue [16,22,30, 31]. De Grip A. et al. (2006) [22] investigated the development of which competencies, whether professional or communicative, has a greater effect on pharmacist satisfaction. In particular, Koval V. et al. (2019) [16] conduct a study in which communicative competencies are defined as determining the competitiveness of a person in the market there and, as a result, the competitiveness of the region.

This is only part of the problems that researchers have been interested in over the past two decades around the world.

\section{METHOD}

\subsection{Participants}

450 undergraduate students in management courses, Economics, Human Resources, 6 universities of the Urals: Ural State Economic University, Ural Federal University, Humanitarian University, Ural Branch of the Ural Branch of the Russian Presidential Academy of National Economy and Public Administration (Ekaterinburg), SUSU State Pedagogical University, MIDIS (Chelyabinsk). 100 representatives of human resources departments and heads of organizations in the Urals.

\subsection{Materials}

To study students' opinions on the importance of communicative competencies for specialists in the field of management and economics, we applied the online questionnaire method. The invitation to participate in the survey was sent to students through social networks, as well as clicking on the link in the QR code of the flyer with information about the study. In the course of the study, the collection, processing and use of personal data of survey participants was not implied. The survey contained questions regarding the importance of the labour market, self-esteem and opportunities for the development of communicative competencies of students during higher education. Similarly, the opinions of 
representatives of the professional community of managers were collected.

\subsection{Results}

As a result of the study, conclusions were drawn regarding the correlation of the opinions of students and managers of enterprises in the Urals regarding the importance, assessment of the level of development and the possibilities of forming the communicative competencies of managers and economists during the period of higher education. Table 1 presents the results of the responses of respondents to two key questions of the questionnaire:

- the assessment of the importance of developing communicative competencies in the labour market;

- the self-esteem by students and assessment of the development of communicative competencies of modern students by representatives of employers.
The survey was conducted on 5 key communicative competencies relevant to the labour market: intersectoral communications, understanding of meanings, media literacy, multilingualism and multiculturalism, negotiating. The assessment was carried out on a scale of 1 to 5 , where 1 is the low demand for competence in the labour market for this group of specialists (low selfesteem, assessment of competence), and 5 - competence is of high importance in the labour market / highly developed among students. For our chosen areas of training within the specialty 38.00.00 "Economics and Management", all 5 communicative competencies are super-professional and from the point of view of representatives of the real sector of the economy have a different level of importance (Table 1).

Table 1 The importance of developing the communicative competencies of HR specialists, self-assessment and assessment of the development of communicative competencies of university graduates ( 5-point scale)

\begin{tabular}{|c|c|c|c|c|c|c|c|c|}
\hline \multirow[t]{2}{*}{ competencies } & importance, $x_{1}$ & self-esteem, $\mathbf{x}_{2}$ & \multirow[t]{2}{*}{$\begin{array}{c}\Delta \mathbf{x}= \\
\mathbf{x}_{1}-\mathbf{x}_{\mathbf{z}}\end{array}$} & importance, $\mathbf{y}_{1}$ & $\begin{array}{c}\text { esteem, } \\
y_{2}\end{array}$ & \multirow[t]{2}{*}{$\begin{array}{c}\Delta \mathbf{y}^{=} \\
\mathbf{y}_{\mathbf{1}}-\mathbf{y}_{\mathbf{z}}\end{array}$} & \multirow[t]{2}{*}{$\mathbf{x}_{1}-\mathbf{y}_{1}$} & \multirow[t]{2}{*}{$\mathbf{x}_{2}-\mathbf{y}_{2}$} \\
\hline & \multicolumn{2}{|c|}{ Students (average) } & & \multicolumn{2}{|c|}{ Employers (average) } & & & \\
\hline $\begin{array}{c}\text { Intersectoral } \\
\text { communication }\end{array}$ & 4.3 & 3.6 & 0.7 & 4 & 3.1 & 0.9 & 0.3 & 0.5 \\
\hline $\begin{array}{l}\text { Understanding of } \\
\text { meanings }\end{array}$ & 4.4 & 3.9 & 0.5 & 4.5 & 3.1 & 1.4 & -0.1 & 0.8 \\
\hline Media literacy & 4.2 & 3.6 & 0.6 & 3.9 & 3.1 & 0.8 & 0.3 & 0.5 \\
\hline $\begin{array}{l}\text { Multilingualism } \\
\text { and } \\
\text { multiculturalism }\end{array}$ & 4.1 & 3.4 & 0.7 & 3.5 & 3.1 & 0.4 & 0.6 & 0.3 \\
\hline Negotiating & 4.6 & 3.6 & 1.0 & 4.5 & 2.9 & 1.6 & 0.1 & 0.7 \\
\hline
\end{tabular}

The main statistics are presented in table 1. The average values of the data on the two questions of the questionnaire have significant differences, at least 0.4 points. On average, students assess the importance of developing communicative competencies for the modern labour market somewhat, but slightly, higher than representatives of employers. Self-assessment of the level of development of students' communicative competencies is much lower than seems necessary for success in the labour market. The most demanded in the labour market of communicative competencies for managers and economists, both students and employers consider the ability to negotiate. At the same time, the largest gap in the indicators of average ratings was identified for the same Negotiating competency. Both students $(\Delta \mathrm{x}=1.0$ points) and to a much more tangible degree employers $(\Delta y$ $=1.6$ ), consider the level of development of students 'negotiating abilities to be inconsistent with the requirements of the modern labour market. The least demand is the competence associated with knowledge of foreign languages and cultures of different countries (4.1 points, importance rating according to students, 3.5 points, importance according to employers). A low assessment of the demand for Multilingualism and multiculturalism is a reason for us to study more deeply, since in the era of globalization, in our opinion, the importance of this competence should be higher. Regarding the issue of assessing and self-assessing the level of development of students' communicative competencies, statistically significant differences in indicators are identified by the "understanding of meanings" and "negotiations" competencies. Students tend to significantly overstate, and employers with a probability of 50/50 underestimate the ability to understand the meaning of the incoming information and negotiate with university students. In general, self-assessment of the level of competencies has significant differences with the assessment of the communicative competencies of students according to employers. Our analysis of variance and verification of the null hypothesis confirmed that group averages for 4 competency assessments generally differ significantly. 
significant statistical differences in the opinions of students and employers regarding the importance of formation, the level of development of modern graduates and students, and also about the possibilities for developing communicative competencies at the university was not confirmed. The results show significant statistical differences, especially in the competence of "negotiating". The most important of the communicative competencies that we selected for the survey, students and employers identified "Negotiating." The competence "Negotiating" revealed the highest gaps in the values of indicators in both sample populations.

Based on the results of the empirical part of the study, we can formulate further directions for studying the opinions of employers and students regarding the possibilities of forming communicative competencies of students:

- study of the opinions of students and employers on the application of modern information technologies in the development of communicative competencies. This study will help to form an idea of the correlation of existing and applied technologies in the educational process with modern technological capabilities. Here we assume that the digital divide problem will be confirmed [e.g. 32.33] and the need to develop digital competencies of higher education teachers;

- study of the possibilities for the development of communicative competencies in the framework of the current Federal State educational standard and approved professional standards. The results of this study will reveal the potential and predict the possibility of forming communicative competencies of students.

In general, the results of the study will become the basis for the development of a methodology for the formation, assessment and development of students' communicative competencies, as one of the essential clusters of professional competencies that ensure the competitiveness of graduates in economics and management in the digital era. competencies in the labour market. As a result of the study, the hypothesis formulated by us that there were no

\section{ACKNOWLEDGMENT}

The research was carried out with the support of the Russian Foundation for Basic Research in the framework of the scientific project No. 1929-07435 Theoretical and methodological

\section{REFERENCES}

[1] L. Bonekamp, M. (2015), "Sure, Consequences of Industry 4.0 on human labour and work organization", Journal of Business and Media Psychology, Vol. 6 (1), pp. 33-40, DOI: https://doi.org/10.3390/economies6030046
[2] Bryndin, E. (2018), "Directions of Development of Industry 4.0, Digital Technology and Social Economy", American Journal of Information Science and Technology, Vol. 2 (1), pp. 9-17, DOI: 10.11648/j.ajist.20180201.12 
[11] Kramsch, C. (2006), "From communicative competence to symbolic competence", The modern language journal, Vol. 90 (2), pp. 249-252, DOI: https://doi.org/10.17223/19996195/38/17

[12] Timoshchuk, N. A. (2015), "The formation of meta-subject competency among students of a technical university", Bulletin of the Samara State Technical University. Series: Psychological and Pedagogical Sciences [Formirovanie metapredmetnoj kompetentnosti u studentov tekhnicheskogo universiteta, Vestnik Samarskogo gosudarstvennogo tekhnicheskogo universiteta. Seriya: psihologopedagogicheskie nauki], No 3 (27), pp. 233-241

[13] Arasaratnam, L. A., Banerjee, S.C. (2011), "Sensation seeking and intercultural communication competence: A model test", International Journal of Intercultural Relations, No 35 (2), pp. 226-233, DOI: https://doi.org/10.1016/j.ijintrel.2010.07.003

[14] Hismanoglu, M., (2011), "An investigation of ELT students' intercultural communicative competence in relation to linguistic proficiency, overseas experience and formal instruction", International Journal of Intercultural Relations, Vol. 35 (6), pp. 805817, DOI: https://doi.org/10.1016/j.ijintrel.2011.09.001

[7] Nelson, L. F. (1978), "Competence of nursing graduates in technical, communicative, and administrative skills", Nursing Research, Vol. 27 (2), pp. 121-125, PMID: 245631

[8] Rosser, H. L. (1979), "Testing oral communicative skills", Foreign Language Annals, Vol. 12 (5), pp. 371373

[9] Kachmarchyk, S., Khrystiuk, S., ShanaievaTsymbal, L. (2019), "Using Blended Learning Technology in Foreign Language Communicative Competence Forming of Future International Relations Specialists", Romanian Journal for Multidimensional Education/Revista Romaneasca pentru Educatie Multidimensionala, Vol. 11, Issue 4, pp. 84-99, DOI: https://doi.org/10.18662/rrem/159

[10] Khayrullina, M.V. (2017), "Formation of economic, managerial and entrepreneurial competencies in a technical university", Russian Entrepreneurship ["Formirovanie ekonomikoupravlencheskih i predprinimatel'skih kompetencij $\mathrm{v}$ tekhnicheskom vuze", Rossijskoe predprinimatel'stvo], Vol. 18 (11), available at: https://cyberleninka.ru/article/n/formirovanieekonomiko-upravlencheskih-i-predprinimatelskihkompetentsiy-v-tehnicheskom-vuze (In Russian)
[15] Smirnov, V. A. (2015), "New competences of a sociologist in the era of "big data", Public Opinion Monitoring: Economic and Social Change ["Novye kompetencii sociologa v epohu bol'shih dannyh", Monitoring obshchestvennogo mneniya], Vol. 2 (125), DOI: https://doi.org/10.14515/monitoring.2015.2.04

[16] Koval, V., Polyezhayev, Y., Bezkhlibna, A. (2019), "Communicative competences in enhancing of regional competitiveness in the labour market", Baltic Journal of Economic Studies ["Kommunikativnye kompetencii $\mathrm{v}$ povyshenii regional'noj konkurentosposobnosti na rynke truda", Baltijskij zhurnal ekonomicheskih issledovanij], Vol. 4 (5), pp. 105-113, DOI: 10.30525 / 2256-0742 / 2018-4-5-105$\underline{113}$

[17] Pesha, A.V. (2019), "Analysis of existing approaches to the formation of pre-professional competencies of graduates of higher educational institutions", Decent work - the foundation of a stable society Materials of the XI International scientificpractical conference ["Analiz sushchestvuyushchih podhodov $\mathrm{k}$ voprosu formirovaniya nadprofessional'nyh kompetencij vypusknikov vysshih uchebnyh zavedenij”, Dostojnyj trud - osnova stabil'nogo obshchestva: materialy XI Mezhdunar. 
context", Higher education, Vol. 38 (3), pp. 291-309, DOI: https://doi.org/10.1023/A:1003866607873

[27] Elboubekri, A. (2017), "The intercultural communicative competence and digital education: The case of Moroccan University students of English in Oujda", Journal of Educational Technology Systems, Vol. 45 (4), pp. 520-545, DOI: https://doi.org/10.1177/0047239516670994

[28] Malakhova, I. A. (2018), "The formation of intercultural competence of students in the process of university education”, Высшая школа: проблемы и перспективы: материалы 13-й Междунар. науч.метод. конф. [“Formirovanie mezhkul'turnoj kompetencii studentov $\mathrm{v}$ processe universitetskogo obrazovaniya", Vysshaya shkola: problemy i perspektivy : materialy 13-j Mezhdunar. nauch.-metod. konf.], RIVSH, Minsk, pp. 264-270, available at: http://elib.bsu.by/handle/123456789/192286 (In Russian)

[29] Canale, M., Swain, M. (1980), “Theoretical bases of communicative approaches to second language teaching and testing", Applied linguistics, Vol. 1 (1), pp. 1-47, DOI: https://doi.org/10.1093/applin/I.1.1

[30] Kochesokova, Z.Kh., Mashekusheva, M.Kh. (2014), "Communicative competencies of police officers as a factor in the effectiveness of professional activities", Modern high technology ["Kommunikativnye kompetencii sotrudnikov policii kak faktor effektivnosti professional'noj deyatel'nosti", Sovremennye naukoemkie tekhnologii], Vol. 4, pp. 167-168, DOI: https://dx.doi.org/10.15405/epsbs.2018.09.02.22

[31] Koropets, O., Fedorova, A. (2018), "Career support of personnel managers during their professional training", Proceedings of the 32nd International Business Information Management Association Conference, IBIMA 2018 - Vision 2020: Sustainable Economic Development and Application of Innovation Management from Regional expansion to Global Growth, International Business Information Management Association, Milan, pp. 2040-2047.

[32] Van Dijk, J. A. (2006), "Digital divide research, achievements and shortcomings", Poetics, Vol. 34 (4-5), $\quad$ pp. 221-235, DOI: https://dx.doi.org/10.1016/j.poetic.2006.05.004

[33] Warschauer, M. (2002), "Reconceptualizing the digital divide", First Monday, Vol. 7 (7), DOI: https://doi.org/10.5210/fm.v7i7.967
[26] Marshall, D., Summer, M., Woolnough, B. (1999), "Students' conceptions of learning in an engineering 